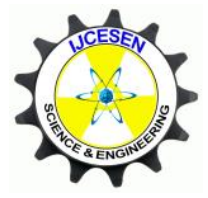

Copyright C IJCESEN
International Journal of Computational and

Experimental $\boldsymbol{S}$ cience and Engineering

(IJCESEN)

Vol. 3-No.1 (2017) pp. 25-28

http://iakkurt.dergipark.gov.tr/ijcesen

Research Article

\title{
Effect of Kaolinite Mass Ratio on Compressive Strength of Kaolinite-Calcite Based Geopolymer \#
}

\author{
Nurşah KÜTÜK*, Sevil ÇETINKAYA
}

Cumhuriyet University, Department of Chemical Engineering, 58140, Sivas, Turkey

* Corresponding Author: nursahkutuk@ hotmail.com

(First received 25 November 2016 and in final form 20 February 2017)

\# Presented in " ${ }^{\text {rd }}$ International Conference on Computational and Experimental Science and Engineering (ICCESEN-2016)"

Keywords
Geopolymers
Compressive strength
Kaolinite
Calcite
Curing temperature

Keywords

Geopolymers

Kaolinite

Curing temperature

\begin{abstract}
This study focuses on the preparation of geopolymers using various proportions of kaolinite and calcite mixture, and the effects of kaolinite mass ratio to calcite on compressive strength of kaolinite/calcite-based geopolymer. Several geopolymer samples were formed using pure kaolinite, pure calcite, and various mass ratio of kaolinite to calcite to examine properties of the geopolymers. The impact of $\mathrm{NaOH}$ concentration on the compressive strength of the geopolymers was also examined. The results of the laboratory analyses indicate that the compressive strength of geopolymers did not increase steadily with increasing concentration of $\mathrm{NaOH}$. The optimum workability of geopolymers was obtained at $10 \mathrm{M} \mathrm{NaOH}$ and $30 \%$ kaolinite content in the mixture. Several sensitivity experiments were carried out using the parameters at cure temperatures of $22,45,65$ and $85^{\circ} \mathrm{C}$. The best compressive strength of $12.68 \mathrm{MPa}$ was obtained on the 28 th day of curing process at $85^{\circ} \mathrm{C}$. The structural evolution of the geopolymers prepared was investigated using FTIR spectroscopy. They were also characterized by X-Ray Diffraction (XRD) and Scanning Electron Microscopy (SEM).
\end{abstract}

\section{Introduction}

Geopolymers based on alumina silicates such as natural raw materials (kaolinite, zeolite, calcite) and industrial wastes (fly ash, granulated blast-furnace slag, silica fume) are a favorable alternative for replacing Portland cement (PC). Specially, the use of waste materials in the construction sector has increased in recent years due to environmental and economic reasons [1,2]. For geopolymerization process, raw materials do not need to be burned at high temperatures as in the case of Portland clinker while alkali active binders are being prepared. For that reason, geopolymers are environmentally friendly materials that do not release $\mathrm{CO}_{2}$ [3]. In addition, geopolymers are of great interested by researchers due to their superior mechanical strength, low shrinkage, acid resistance, fire resistance and low thermal conductivity [4]. The primary step of geopolymerization is the dissolution of the solid alumina silicate oxide in a $\mathrm{KOH}$ or $\mathrm{NaOH}$ solution to form free $\mathrm{SiO}_{4}$ and $\mathrm{AlO}_{4}$ tetrahedral units. Alkali activation of these raw materials results in three-dimensional alumina silicate structure which display better mechanical strength properties such as compression strength [5]. The main product formed in the geopolymeric system is either sodium alumina silicate gel N-A-S$\mathrm{H}\left(\mathrm{Na}_{2} \mathrm{O}-\mathrm{Al}_{2} \mathrm{O}_{3}-\mathrm{SiO}_{2}-\mathrm{H}_{2} \mathrm{O}\right)$ or calcium alumina silicate hydrate gel type C-A-S-H $\left(\mathrm{CaO}-\mathrm{Al}_{2} \mathrm{O}_{3}-\right.$ $\mathrm{SiO}_{2}-\mathrm{H}_{2} \mathrm{O}$ ) as depend on the content of the raw material [6,7]. Polymer formation rate during geopolymerization is affected by such parameters as curing temperature, curing day, alkali concentration, water content and initial solids content [4]. As useful construction materials such as kaolinite could be hardened and transformed into geopolymers therefore kaolinite is an alternative alumina silicate source for geopolymerization [8,9]. Herein, we aimed to prepare the most suitable geopolymers using various proportions of kaolinite and calcite mixture for building industry. The effects of curing time, curing temperature and $\mathrm{NaOH}$ concentration and kaolinite mass ratio on the 
compression strength of prepared geopolymers were investigated.

\section{Experimental}

$\mathrm{NaOH}$ and kaolinite were mixed in a beaker for 5 min. Then calcite was added and mixed for $5 \mathrm{~min}$. Finally, $\mathrm{Na}_{2} \mathrm{SiO}_{3}$ was added and mixed for $15 \mathrm{~min}$ and then the fresh cement was rapidly poured into a cubic steel mold of $40 \times 40 \times 40 \mathrm{~mm}^{3}$. In order to investigate the effect of the activator on the properties of the geopolymer material, a series of $\mathrm{NaOH}$ solution with concentrations of 5, 10, 15 and $20 \mathrm{M}$ and $\mathrm{Na}_{2} \mathrm{SiO}_{3} / \mathrm{NaOH}$ weight ratio of $0.5,1,1.5$ and 2 were used. Varying curing temperatures were applied on the prepared geopolymers such as 22, 45,65 and $85^{\circ} \mathrm{C}$.

\section{Results and Discussion}

$\mathrm{NaOH}$ concentration, $\mathrm{Na}_{2} \mathrm{SiO}_{3} / \mathrm{NaOH}$ weight ratio, curing temperature and curing day are the most important parameters in geopolymer production [4]. The effect of $\mathrm{Na}_{2} \mathrm{SiO}_{3} / \mathrm{NaOH}$ weight ratio on the compressive strength is plotted in Fig 1. It was observed that compressive strength of the geopolymer increases as the $\mathrm{Na}_{2} \mathrm{SiO}_{3} / \mathrm{NaOH}$ weight ratio increases. The best compressive strength was reached $(9.12 \mathrm{Mpa})$ when $\mathrm{Na}_{2} \mathrm{SiO}_{3} / \mathrm{NaOH}$ weight ratio was 2.

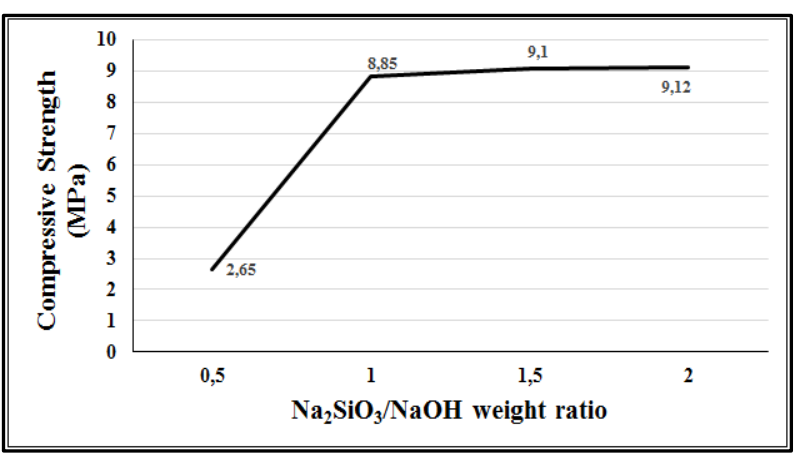

Figure 1. The effect of $\mathrm{Na}_{2} \mathrm{SiO}_{3} / \mathrm{NaOH}$ weight ratio on the compressive strength.

Fig 2. shows the effect of percent of kaolinite in the mixture with various $\mathrm{NaOH}$ concentration and curing temperature on the compressive strength. It is seen from the figures that the highest compressive strength of the geopolymers was at $80 \%$ kaolinite in the mixture at $20 \mathrm{M} \mathrm{NaOH}$ concentration (Fig 2a). Although the compressive strength increased with the $\mathrm{NaOH}$ concentration, because of the deterioration and hard workability of
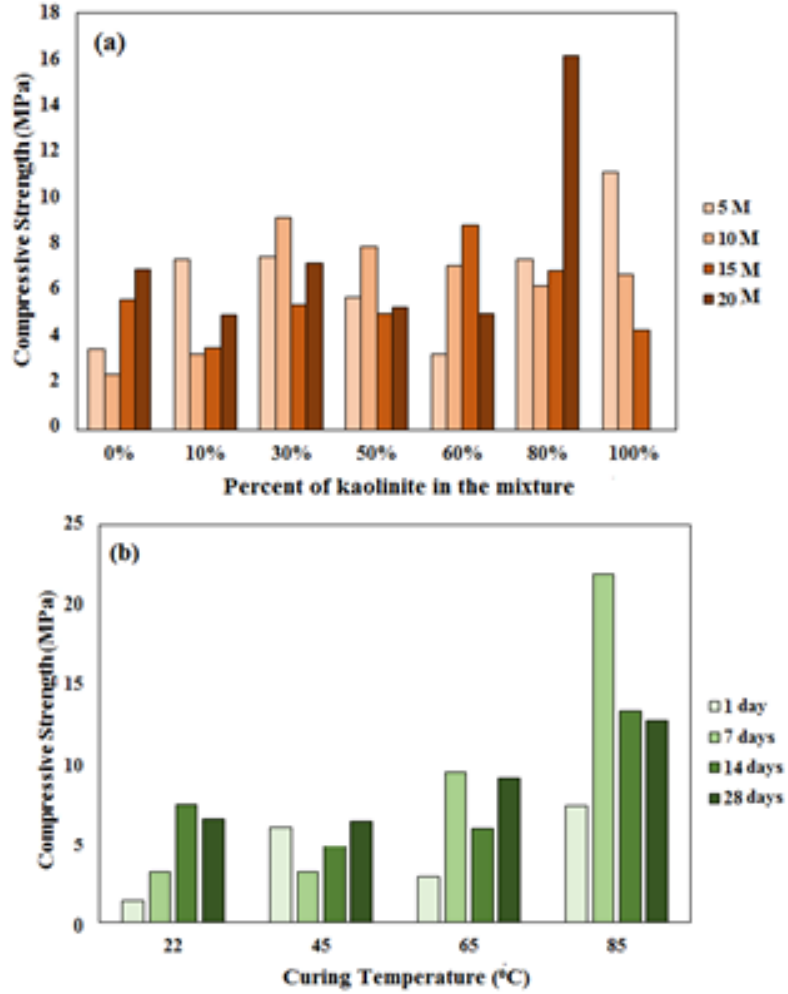

Figure 2. (a) The effect of percent by weight of kaolinite in the mixture b) curing temperature on the compressive strength

the samples at high $\mathrm{NaOH}$ concentration, 30\% kaolinite content in the mixture and $10 \mathrm{M} \mathrm{NaOH}$ concentration was chosen as the best experimental conditions for preparation of geopolymers (Fig 2a). Compressive strength of geopolymer samples increases along with increase curing temperature and days (Fig 2b). Curing temperature at $85^{\circ} \mathrm{C}$ was used for preparing for all geopolymer samples because the highest compressive strength reached on the 28th day of curing process at $85^{\circ} \mathrm{C}$. The highest compressive strength was obtained as 12 , $68 \mathrm{MPa}$ at the $28^{\text {th }}$ day of curing process at $85^{\circ} \mathrm{C}$ (30\% kaolinite content and $10 \mathrm{M} \quad \mathrm{NaOH}$ concentration, Fig 2b).

Fig. 3a illustrates the FTIR spectra of calcite, kaolinite and geopolymers at different curing temperature on the $28^{\text {th }}$ day of curing process. The band at $3686 \mathrm{~cm}^{-1}$ corresponds to $\mathrm{Si}-\mathrm{O} / \mathrm{Al}-\mathrm{O}$ vibrations which belongs to kaolinite [4]. In addition, the characteristic calcite peaks observed at 1393,871 and $711 \mathrm{~cm}^{-1}$ indicate $\mathrm{CO}_{3}{ }^{2-}$ asymmetric stretching, $\mathrm{CO}_{3}{ }^{2-}$ out-of-plane, and $\mathrm{CO}_{3}{ }^{2-}$ in-plane bending, respectively [10]. The characteristic peaks of kaolinite and calcite were also observed from FTIR spectra of geopolymers as seen in Fig. 3a. These results clearly show the presence of unreacted kaolinite and calcite particles in the geopolymer. 

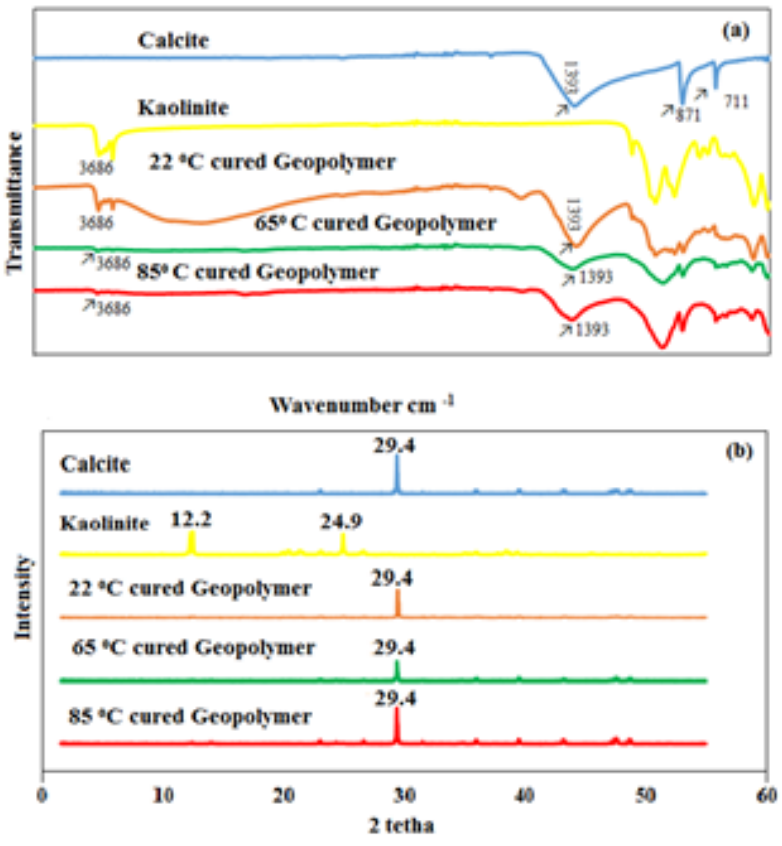

Figure 3. (a) FTIR spectrum and (b) XRD patterns of calcite, kaolinite and geopolymers with various curing temperature $(30 \%$ kaolinite content in the mixture, $10 \mathrm{M}$ $\mathrm{NaOH}$ and $28^{\text {th }}$ day of curing process).

As seen in figure $3 \mathrm{~b}$, the characteristic diffraction peaks of kaolinite and calcite were located at 12.2, 24.9 and $29.4^{\circ}(2 \theta)$. The characteristic diffraction peaks of kaolinite disappeared in all geopolymer samples after geopolymerization process [4]. The peaks of the prepared geopolymers were observed around $29^{\circ}(2 \theta)[11]$.

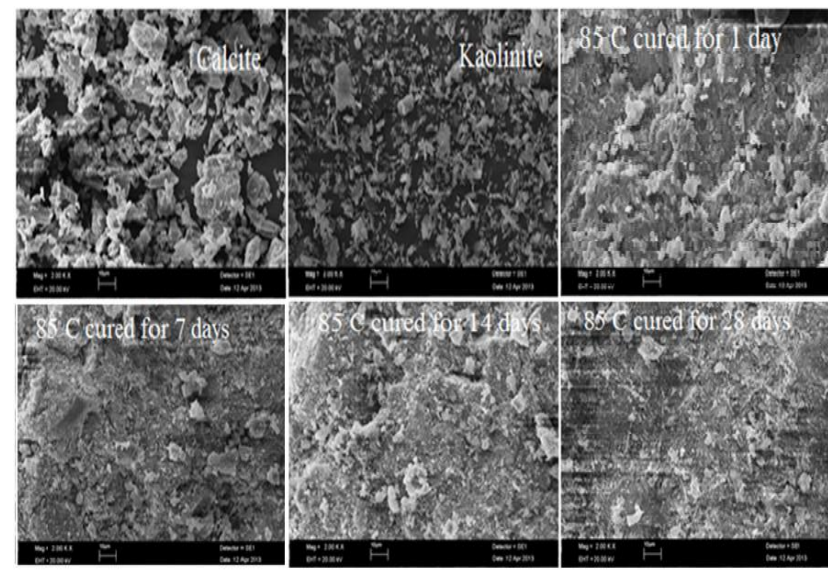

Figure 4. SEM micrographs of calcite, kaolinite and $85^{\circ} \mathrm{C}$ cured geopolymers

SEM micrographs of geopolymers exhibit significant change in the microstructure with increased curing time (Fig. 4). It is seen that the geopolymers are more dense and homogeneous as curing day increases and have a more hardened structure at $28^{\text {th }}$ day.

\section{Conclusion}

In this study, kaolin and calcite were used together to prepare geopolymer and the effect of kaolin on compressive strength was analyzed. Kaolinitecalcite based geopolymer materials have been successfully synthesized various mass ratio of kaolinite to calcite using aqueous solution of alkali silicate and $\mathrm{NaOH}$. \%. It was observed that when the amount of kaolin was $80 \%$ and the concentration of $\mathrm{NaOH}$ was $20 \mathrm{M}$, although the compression strength was the highest, there was deterioration in the structure of the sample. Therefore, the optimum compressive strength was reached at a $\mathrm{Na}_{2} \mathrm{SiO}_{3} / \mathrm{NaOH}$ mass ratio of 2 , when the $\mathrm{NaOH}$ concentration was $10 \mathrm{M}$ and at curing time at $85^{\circ} \mathrm{C}$ on the 28th day. The results of this formulation were obtained when the amount of kaolin in the mixture was 30 . The amount of kaolin in the geopolymer was found to be important in terms of compressive strength. Calcite material has been found to improve the roughness, rapid freezing and shaping of geopolymer samples

\section{Acknowledgement}

This work was supported by Cumhuriyet University Scientific Research Project (CUBAP), project numbered as M474.

\section{References}

[1] Villa, C., E.T.Pecina, R.Torres, L.Gomez "Geopolymer synthesis using alkaline activation of natural zeolite" Construction and Building Materials. 24 (2010) 2084-2090

[2] Beycioğlu, A., C.Başyiğit "Rule-Based MamdaniType Fuzzy Logic Approach to Estimate Compressive Strength of Lightweight Pumice Concrete" ACTA PHYSICA POLONICA A. 128(2B) (2015) 424-426

[3] Kusak, I., M.Lunak, P.Rovnanik "Electric conductivity changes in geopolymer samples with added carbon nanotubes" Procedia Engineering 151 ( 2016 ) $157-161$

[4] Heah, C., Y., H Kamarudin, A.M.Mustafa Al Bakri, M.Bnhussain, M. Luqman, I.Khairul Nizar, C.M.Ruzaidi Y.M.Liew "Study on solids-to-liquid- and alkaline activator ratios on kaolin-based geopolymers" Construction and Building Materials. 35 (2012) 912-922 [5] Autef, A., E.Joussein, G.Gasgnier, S.Pronier, I.Sobrados, J.Sanz, S. Rossignol "Role of metakaolin dehydroxylation in geopolymer Synthesis" Powder Technology. 250 (2013) 33-39

[6] Lee, N., K., E.M.Kim, H.K.Lee "Mechanical properties and setting characteristics of geopolymer 
mortar using styrene-butadiene (SB) latex" Construction and Building Materials. 113 (2016) 264-272

[7] Mijarsh, M., J., A., M.A.Megat Johari, Z.A.Ahmad "Synthesis of geopolymer from large amounts of treated palm oil fuel ash: Application of the Taguchi method in investigating the main parameters affecting compressive strength" Construction and Building Materials 52 (2014) 473-481

[8] Alshaaer, M., B.El-Esweed, R.I.Yousef, F.Khalili, H.Rahier "Development of functional geopolymers for water purification, and construction purposes" Journal of Saudi Chemical Society. 20 (2016) 85-92

[9] Alshaaer, M. "Two-phase geopolymerization of kaolinite-based geopolymers" Applied Clay Science. 86 (2013) 162-168

[10]Fiocco, L., B.Michielsen, E.Bernardo "Silicabonded apatite scaffolds from calcite-filled preceramic polymers" Journal of the European Ceramic Society. 36 (2016) 3211-3218

[11] Provis, J., L., P.Duxson, J.S.J.Van Deventer, G.C.Lukey "The Role of Mathematical Modelling and Gel Chemistry in Advancing Geopolymer Technology" Chemical Engineering Research and Design. 83 (2005) 853-860 